耳管狭窄に対するマクロライドの効果

高桑由紀子 ${ }^{1)}$ ・高橋 晴雄 ${ }^{1)} \cdot$ 須藤 正治 ${ }^{2)} \cdot$ 田辺 牧人 ${ }^{3)}$

\title{
Effect of Low-dose Long-term Treatment with Macrolide for Intractable Eustachian Tube Stenosis
}

\author{
Yukiko Takakuwa and Haruo Takahashi \\ (Kyoto University) \\ Masaharu Sudo \\ (Fukui Red-Cross Hospital) \\ Makito Tanabe \\ (Kobe City General Hospital)
}

\begin{abstract}
The efficacy of low-dose long-term macrolide for treatment of intractable eustachian tube (ET) stenosis in 20 patients ( 21 ears) with otitis media with effusion or chronic suppurative otitis media was evaluated. A single daily dose $(400 \sim 500 \mathrm{mg})$ of erythromycin or clarithromycin was administered for 2 7 months, and ET function was assessed by a modified inflation-deflation test or catheter inflation before and after the course of medication. ET stenosis improved in 10 of the 21 ears (47.6\%). The rate of improvement was higher in patients with chronic sinusitis than in those without chronic sinusitis. These results indicate that low-dose long-term macrolide treatment may be useful for treatment of intractable ET stenosis.
\end{abstract}

Key words : Eustachian tube function, otitis media, macrolide

\section{はじめに}

中耳疾患の治療において，耳管の器質的と考兄られる 難治性の狭窄・閉塞は, 長期にわたる中耳の炎症による 耳管の骨新生あるいは軟部組織肥厚の結果であると考え られるが，これに対する有効な治療法は現在すで確立さ れていない11 〜2).

近年衆知のよらに, びょん性沉細気管支炎や慢性副鼻 腔炎等の上気道の慢性炎症に対してマクロライド少量長

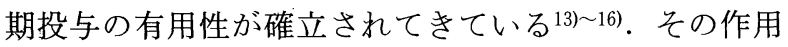
機序は, 好中球や単球・リンパ球・ NK 細胞・線毛細胞 - 粘液産生細胞等, 種々の炎症・免疫担当細胞に働いて
粘液過剩分泌の抑制, 線毛運動の活性化をはじめ抗炎症 効果をもたらし, 細菌の定着, 増殖に関係する環境を改 善する非抗菌作用の可能性が高いといわれている17) 199. このことから, 同様の気道粘膜上皮をもつ耳管粘膜の病 变にも本療法が有用である可能性が示唆される.

今回我々は, 難治性の耳管狭窄を伴う中耳炎症例に対 してマクロライドの少量長期投与を行い良好な成績を得 たので予報的に報告する．

\section{対象と方法}

対象は，1995年10月より1997年 9 月までの間に当科を

1）京都大学医学部附属病院耳鼻咽喉科

2）福井日本赤十字病院耳鼻咽喉科

3）神戸市立中央市民病院耳鼻咽喉科 
受診した難治性の耳管狭窄・閉塞を伴った中耳炎症例 20 例21耳で, 慢性中耳炎 8 耳, 滲出性中耳炎 9 耳, 癒着性 中耳炎 4 耳である(表 1 ).

マクロライドは18例でエリスロマイシン，2 例でクラ リスロマイシンを使用し，1日 1 回 400～500 mg を経 口投与とした. 投与期間は 2 力月から 7 力月で平均 4.3 カ月であった。

耳管狭窄・閉塞の判定は, 鼓膜穿孔耳に打いては加圧 ・減圧法により受動的耳管開大圧を測定し，その他の症 例に捈いてはカテーテル耳管通気により行った. 耳管開 大圧 $800 \mathrm{mmH}_{2} \mathrm{O}$ 以上, もしくはカテーテル耳管通気が 不通の症例を耳管狭窄・閉塞とし, マクロライ.ド投与後 に再検して，耳管開大圧の低下の見られた症例，あるい
は耳管通気が開通した症例を改善例とした。

またCT あるいは鼻レントゲン写真にて副鼻腔炎の有 無を調べ，本治療の効果との相関を調べた.

\section{結果}

まず代表的症例を呈示する.

症例 1 46歳, 女性. 右滲出性中耳炎.

29歳時より右渗出性中耳炎に罹患し，鼓膜チューブ留 置を計 7 回行ったがチューブ脱落の度に再発を繰り返し ていた. 副鼻腔炎の既往はなかった。

耳管機能検査では初診時より右耳管通気不通で，再三 の検査で耳管開大圧が $800 \mathrm{mmH}_{2} \mathrm{O}$ 以上を示した.

1996年 5 月 27 日よりエリスロマイシン $400 \mathrm{mg}$ を 3 カ

表 1 マクロライド投与前後の耳管機能所見

\begin{tabular}{|c|c|c|c|c|c|c|c|}
\hline \multirow{2}{*}{ No. } & \multirow{2}{*}{ 年齢 } & \multirow{2}{*}{ 性別 } & \multirow{2}{*}{ 疾患 } & \multirow{2}{*}{$\begin{array}{c}\text { 投与期間 } \\
\text { (月) }\end{array}$} & \multicolumn{2}{|c|}{ 耳管開大圧 $\left(\mathrm{mmH}_{2} \mathrm{O}\right)$} & \multirow{2}{*}{$\begin{array}{c}\text { 副鼻腔炎 } \\
\text { 有無 }\end{array}$} \\
\hline & & & & & 投与前 & 投与後 & \\
\hline 1 & 21 & 女 & 慢性中耳炎 & 3 & $>800$ & $440^{*}$ & - \\
\hline 2 & 62 & 女 & 慢性中耳炎 & 3 & $>800$ & $480^{*}$ & - \\
\hline 3 & 51 & 女 & 慢性中耳炎 & 6 & $\mathrm{LD}$ 狭窄 & $200^{*}$ & - \\
\hline 4 & 53 & 男 & 慢性中耳炎 & 2 & LD 閉塞 & $340^{*}$ & + \\
\hline 5 & 44 & 男 & 疹出性中耳炎 & 3 & $>800$ & $750^{*}$ & - \\
\hline 6 & 58 & 男 & 滲出性中耳炎 & 3 & $>800$ & $500^{*}$ & - \\
\hline 7 & 46 & 女 & 參出性中耳炎 & 3 & $>800$ & $740^{*}$ & - \\
\hline 8 & 28 & 男 & 參出性中耳炎 & 4 & $>800$ & $390^{*}$ & + \\
\hline 9 & 74 & 女 & 滲出性中耳炎 & 4 & $\mathrm{LD}$ 閉塞 & $200^{*}$ & + \\
\hline 10 & 69 & 女 & 癒着性中耳炎 & 4 & $\mathrm{LD}$ 狭窄 & $580^{*}$ & - \\
\hline 11 & 75 & 男 & 慢性中耳炎 & 4 & $>800$ & $>800$ & - \\
\hline 12 & 51 & 女 & 慢性中耳炎 & 6 & $\mathrm{LD}$ 閉塞 & $>800$ & - \\
\hline 13 & 48 & 女 & 慢性中耳炎 & 5 & $\mathrm{LD}$ 閉塞 & LD 狭窄 & - \\
\hline 14 & 56 & 女 & 慢性中耳炎 & 2 & $\mathrm{LD}$ 閉塞 & LD 閉塞 & + \\
\hline 15 & 23 & 男 & 參出性中耳炎 & 3 & $>800$ & $>800$ & - \\
\hline 16 & 15 & 男 & 參出性中耳炎 & 3 & $>800$ & $>800$ & - \\
\hline 17 & 50 & 男 & 參出性中耳炎 & 7 & $>800$ & $>800$ & - \\
\hline 18 & 50 & 男 & 滲出性中耳炎 & 7 & $>800$ & $>800$ & - \\
\hline 19 & 70 & 女 & 癒着性中耳炎 & 7 & $>800$ & $>800$ & - \\
\hline 20 & 35 & 女 & 癒着性中耳炎 & 4 & $>800$ & $>800$ & - \\
\hline 21 & 45 & 男 & 癒着性中耳炎 & 7 & $>800$ & $\mathrm{LD}$ 狭窄 & - \\
\hline
\end{tabular}

LD: カテーテル耳管通気

* : 耳管機能の改善が見られた症例 
月間経口投与した．投与後の耳管機能検査で耳管開大圧 は $740 \mathrm{mmH}_{2} \mathrm{O}$ と改善し，その後は鼓膜留置チューブが 自然脱落した後も現在まで約 8 力月渗出性中耳炎の再発 は見られず，聴力も改善し良好に経過している(図1).

症例 263 歳, 女性. 左慢性中耳炎.

幼少時より中耳炎の既往があり，耳漏を年に 2,3 回 繰り返していた．鼓膜には中心性穿孔が認められた。

耳管機能検査では耳管開大圧は $800 \mathrm{mmH}_{2} \mathrm{O}$ 以上を示 し，耳管カテーテル通気でも不通であった。エリスロマ イシン $400 \mathrm{mg}$ を約 3 カ月間経口投与した. 投与後の耳 管機能検查で耳管開大圧は $480 \mathrm{mmH}_{2} \mathrm{O}$ と正常化し, 耳 管通気も良好となった。初診 8 力月後に左鼓膜形成術を 施行し, 現在術後約 8 カ月であるが，滲出液の貯留もな く経過良好である．初診時执よび現時点での聴力図を示 于(図 2 ).

今回対象とした全症例の一覧を表 1 亿示す．本療法に よりマクロライド投与前後に耳管狭窄の改善が見られた 症例は 21 耳中 10 耳で，全体の $47.6 \%$ 占めた。また，前 後に耳管開大圧を定量的に測定できた確実例13例のうち でも 6 例と, 半数弱に有効性が見られた.

また，全症例のらちで，慢性副鼻腔炎を合併していた 症例は 4 例であり, そのなかでは 3 例に耳管機能の改善 が見られた。

な拈，マクロライド投与中に重大な副作用の見られた

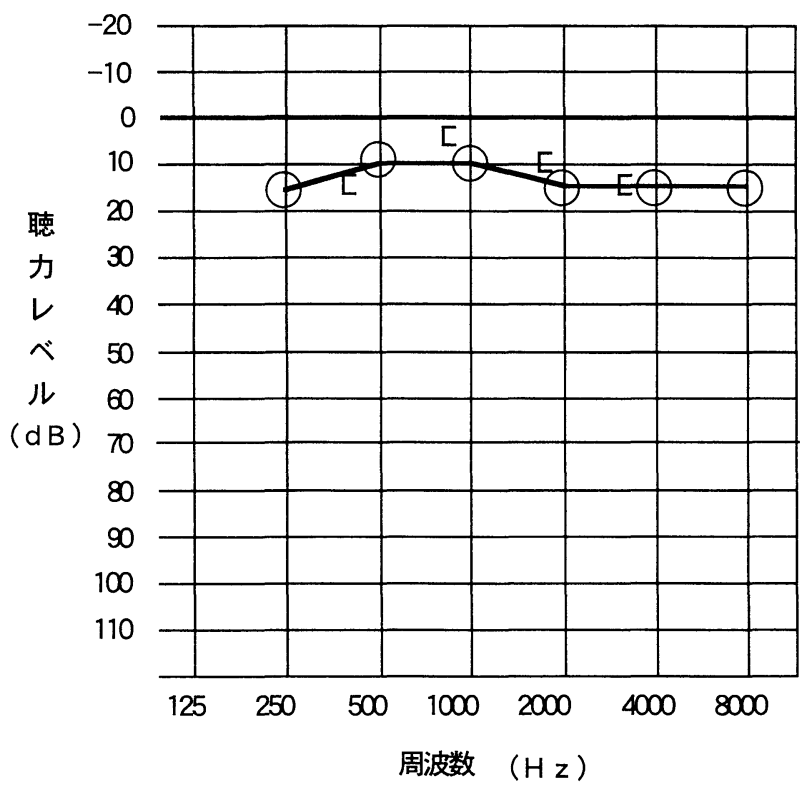

図 1 症例 1 のエリスロマイシン投与後の聴力

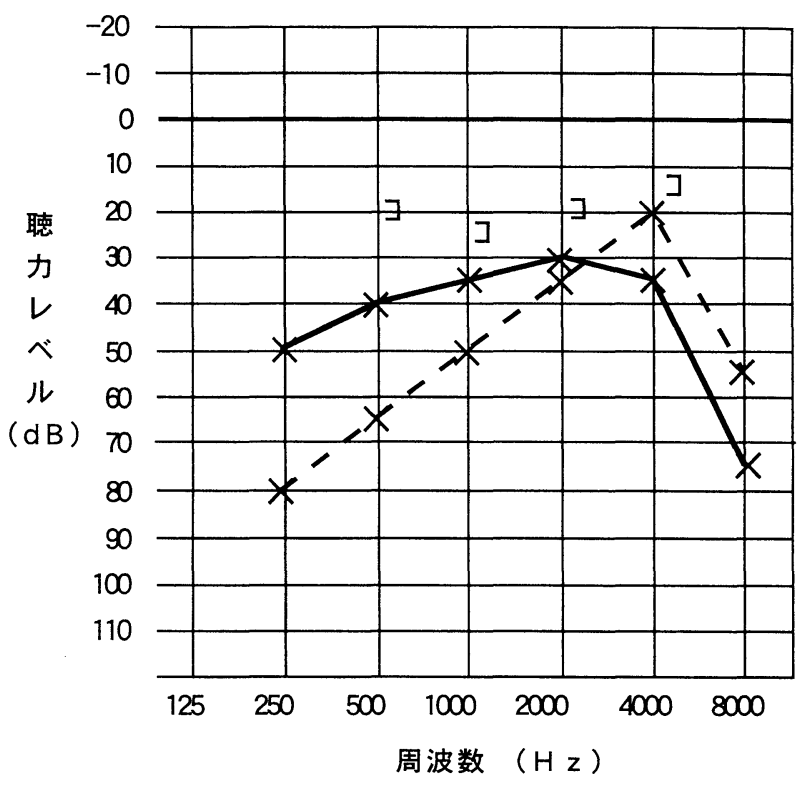

図 2 症例 2 の術前聴力 (点線) と術後聴力(実線)

症例はなかった。

\section{考按}

中耳炎に伴う耳管の難治性狭窄・閉塞は，長期にわた る中耳，耳管の炎症の結果であると同時に各種中耳疾患 の遷延化，難治化の原因となり得る122)。これまでその 治療汇関しては，耳管バイパス術3)，耳管内挿管・開放 術45), 耳管咽頭ロレーザー開大術年等の外科的治療法や, 鼻粘膜収縮剤の鼻内投与(7) 9)， $\beta$-アゴニスト内服，サー ファクタント耳管内注入による効果 ${ }^{10)}$ 等報告されてい るが，その有効性は確立されているとはい方ないまた， マクロライドについては，守田ら ${ }^{111212) か ゙ ロ キ シ ス ロ マ イ ~}$ シン $(\mathrm{RXM})$ による効果を報告しているが，今回の観察 で我々は改めて難治性の耳管狭窄・閉塞性病変に対する マクロライド投与効果を定量的に確認できた。

今回の症例では，本療法によりマクロライド投与前後 に耳管換気機能の著明な改善が見られた症例は全体の約 半数の $47.6 \%$ 占め，また治療前後に耳管機能を定量的 に測定できた確実例13例中でも 6 例と半数程度に有効で あり，本治療法が従来確実な治療法がなかった耳管狭窄 に対する有効な治療法となりらる可能性が示唆された.

マクロライドの慢性副鼻腔炎に対する有用性は確立さ れているが14) 16)，副鼻腔炎のある症例に限ってみると 4 例中 3 例の耳管狭窄が改善され，鼻疾患のない症例と 
比べより耳管機能改善効果が期待できると考えられる. 注かにも慢性副鼻腔炎を合併する沴出性中耳炎症例に対 するマクロライドの有用性を認める報告があり ${ }^{20)}$, 鼻粘 膜病態の改善はマクロライドの耳管機能改善の作用機序 の1つとして考觉られるが，慢性副鼻腔炎を合併してい ないその他の症例17例中でも 7 例に耳管機能の改善が見 られていることから，それのみではなく敢管粘膜自体に も何らかの直接作用を及洼していると考兄られる。その 作用機序はやはりびまん性肺炎や副鼻腔炎での機序と同 様に，非抗菌作用の可能性がむしろ高い17 199.

本療法は中耳や鼻咽腔に侵襲を与兄ず, 重篤な副作用 もないことから啇応は広く, 今回対象とした難治例のみ でなく軽症例にも初回治療として試みる価值があると考 えられる. 症例によっては症例 1 のように難治性の渗出 性中耳炎であっても本療法により治癒が期待でき，また 症例 2 のよらに耳管高度狭窄のある慢性中耳炎でも術前 のマクロライド使用により良好な術後経過が期待できる など，本療法の意義は大きいと考兄られ，今後もマク口 ライドの積極的な試用を進めその適応などもさらに分析 していきたいと考えている.

\section{まとめ}

耳管高度狭窄・閉塞例21耳に対しマクロライドの少量 長期投与療法を行い，約半数で良好な結果を得た。本療 法は耳管狭窄・閉塞症例に対し試みる価值のある方法と 考えられた。

本論文の要旨は第67回日本耳鼻咽喉科学会京滋合同地方部会 に批いてロ演した。

\section{参考文献}

1) Honjo I, Takahashi H, Fujita A, et al : Etiology of otitis media with effusion; tubal dysfunction or infection. Recent Advances in Otitis Media (ed by Mogi G, Honjo I, Ishii T, et al). pp 49 51, Kugler Publications, Amsterdam/ New York, 1994.

2) Lamp CB : Chronic secretory otitis media; etiologic factors and pathologic mechanisms. Laryngoscope $83: 276$ $\sim 291,1973$.

3) Lapidot A and Rubenstein A: Eustachian tube bypass. IMJ Ill Med J 166 : 354 355, 1984.

4) Zhu MJ : Eustachian intubation. Recent Advances in Otitis Media (ed by Mogi G, Honjo I, Ishii T, et al). pp 795
797, Kugler Publications, Amsterdam/New York, 1994.

5 ) Zini C, Bacciu S, Scandellari R, et al : Intra-operative management of the osseous eustachian tube. Cholesteatoma and Mastoid Surgery (ed by Tos M, Thomsen J and Peitersen E). pp 533 541, Kugler \& Ghedini Publications, Amsterdam/Berkeley/Milano, 1989.

6) Honda $K$, Tanke $M$ and Kumazawa $T$ : Treatment of eustachian tube dysfunction-laser surgery and two therapeutic methods. Recent Advances in Otitis Media (ed by Lim DJ, Bluestone CD, Klein JO, et al). pp 278 280, BC Decker Inc, Tront/Philadelphia, 1987.

7) Olen $\mathrm{L}$ and Holmquist $\mathrm{J}$ : Influence of nasal decongestants on eustachian tube function. Recent Advances in Otitis Media (ed by Lim DJ, Bluestone CD, Klein JO, et al). pp 83 85, Decker Periodicals, Florida, 1993.

8 ) Jensen JH, Leth $\mathrm{N}$ and Bonding $\mathrm{P}$ : Topical application of decongestant in dysfunction of the eustachian tube ; a randomized, double blind, placebo-controlled trial. Clin Otolaryngol $15: 197 \sim 201,1990$.

9 ) Lildholdt T, Cantekin EI, Bluestone CD, et al : Effect of a topical nasal decongestant on eustachian tube function in children with tympanostomy tubes. Acta Otolaryngol $94: 93 \sim 97,1982$.

10) Malm $L$ and White $P$ : Beta-agonist and surfactant in eustachian tube function. Acta Otolaryngol (Stockh) Suppl 493 : 133 136, 1992.

11）守田雅弘, 原田 保, 久保 武: 出性中耳炎の耳管機能 とロキシスロマイシン. 耳鼻臨床 補74 : 28, 1994.

12) Morita $M$, Harada $T$ and Kubo $T$ : Tubal function in otitis media with effusion and treatment with roxithromycin. Recent Advances in Otitis Media (ed by Lim DJ, Bluestone CD, Casselbrant M, et al). pp 213 215, BC Decker Inc, Ontario, 1996.

13）工藤翔二，木村 亿，植竹健司：びまん性沉細気管支炎に 対するマクロライド系抗生剂の少量長期投与. 日胸疾会誌 22 増: 254, 1984.

14）洲崎春海, 杉田公一，工藤翔二，他：エリスロマイシンは どのような疾患・病態に有効かびまん性沉気管支炎に併 発する慢性副鼻腔炎に対する効果. Therapeutic Research $11: 961 \sim 963,1990$.

15）菊地 茂, 洲崎春海, 青木彰彦, 他: 副鼻腔炎とエリスロ マイシン長期少量投与. 耳鼻臨床 $84: 41 \sim 47,1991$.

16）洲崎春海：慢性副鼻腔炎へのマクロライド療法の応用の開 始と現状. JOHNS $12: 213 \sim 220,1996$.

17) Anderson R : Erythromycin and roxithromycin potentiate human neutrophil locomotion in vitro by inhibition of leukoattractant-activated superoxide generation and autooxidation. J Infect Dis 159 : 966 973, 1989. 
18) Keicho N, Kudoh S, Yotsumoto H, et al : Erythromycin promotes monocyte to macrophage differentiation. J Antibiotics $47: 80 \sim 89,1994$.

19）森 繁人, 斎藤 等, 木村有一, 他: マクロライド系抗生 剤の鼻粘膜繊毛運動に及ぼす影響. 耳展 38 補 $3: 220$ 〜 227, 1995

20) Kurata K, Takahashi H, Fujita A, et al : Clinical efficacy of clarithromycin treatment of refractory otitis media with effusion. Recent Advances in Otitis Media (ed by Lim DJ, Bluestone CD, Casselbrant M, et al). pp 236 238, BC Decker Inc, Ontario, 1996.

$$
\left.\begin{array}{l}
\text { 原稿受付 : 平成 } 9 \text { 年 } 10 \text { 月 } 30 \text { 日 } \\
\text { 原稿採択 : 平成 } 9 \text { 年 } 12 \text { 月 } 3 \text { 日 } \\
\text { 別刷請求先 : 高桑由紀子 } \\
\text { 干 } 606-8507 \text { 京都市左京区聖護院川原町 } 54 \\
\text { 京都大学医学部附属病院耳鼻咽喉科 }
\end{array}\right)
$$

